\title{
Cannabis: A Prehistoric Remedy for the Deficits of Existing and Emerging Anticancer Therapies
}

\author{
Bakht Nasir $^{1}$, Humaira Fatima ${ }^{1}$, Madiha Ahmed ${ }^{1}$, Abdul-Rehman Phull ${ }^{2}$ and Ihsan-ul-Haq ${ }^{*}$ \\ ${ }^{1}$ Department of Pharmacy, Faculty of Biological Sciences, Quaid-i-Azam University, Islamabad, Pakistan; ${ }^{2}$ Department of Biological Sci- \\ ences, College of Natural Sciences, Kongju National University, 56 Gongju Daehak-Ro Gongju-Si, Chungnam 32588, Republic of Korea
}

\begin{abstract}
Cannabis has been used medicinally for centuries and numerous species of this genus are undoubtedly amongst the primeval plant remedies known to humans. Cannabis sativa in particular is the most reported species, due to its substantial therapeutic implications that are owed to the presence of chemically and pharmacologically diverse cannabinoids. These compounds have long been used for the palliative treatment of cancer. Recent advancements in receptor pharmacology research have led to the identification of cannabinoids as effective antitumor agents. This property is accredited for their ability to induce apoptosis, suppress proliferative cell signalling pathways and promote cell growth inhibition. Evolving lines of evidence suggest that cannabinoid analogues, as well as their receptor agonists, may offer a novel strategy to treat various forms of cancer. This review summarizes the historical perspective of $C$. sativa, its potential mechanism of action, and pharmacokinetic and pharmacodynamic aspects of cannabinoids, with special emphasis on their anticancer potentials.
\end{abstract}

\section{Introduction}

\section{Cannabis}

Cannabis in both its pure and altered forms has been beneficial for human use since antiquity. ${ }^{1}$ Members of the genus Cannabis mostly produce dioecious annual herbs. ${ }^{2,3}$ The exact number of Cannabis species is a point of great debate, as according to different researchers there are variable number of species. ${ }^{4-10}$ The species that are most pertinent include, Cannabis sativa, Cannabis ruderalis and Cannabis indica. However, among these, the highly polymorphic species Cannabis sativa L. is considered as the most active, based on studies targeting its morphology, anatomy, phyto-

Keywords: Cannabis sativa; Cannabinoids; Psychoactive agents; Cancer therapy. Abbreviations: ACF, aberrant crypt foci; CB1, cannabinoids receptor type 1; CB2, cannabinoids receptor type 2; CBC, cannabichromene; $\mathrm{CBD}$, cannabidiol; $\mathrm{CBE}$, cannabielsoin; CBG, cannabigerol; CBL, cannabicyclol; CBN, cannabinol; CBND, cannabinodiol; CBT, cannabitriol; COX1, cyclooxygenase 1; COX2, cyclooxygenase 2; CRC, colorectal carcinoma; EGFR, epidermal growth factor receptor; ERK, extracellular signal-regulated kinase; HCC, hepatocellular carcinoma; HER2, human epidermal growth factor receptor 2; iNOS, inducible nitric oxide synthase; MCL, mantle cell lymphoma; MMTV, mouse mammary tumour virus; $221^{\text {ras }}$, K-ras oncogene product; PKA, protein kinase A; PPAR $\gamma$, peroxisome proliferator activated receptor gamma; THC, tetrahydrocannabinol; TNF, tumour necrosis factor; TRP, transient receptor potential; VEGF, vascular endothelial growth factor.

Received: March 22, 2017; Revised: June 21, 2017; Accepted: June 22, 2017

*Correspondence to: Ihsan-ul-Haq, Department of Pharmacy, Faculty of Biological Sciences, Quaid-i-Azam University, Islamabad 45320, Pakistan. Tel: +92-5190644143,E-mail: ihsn99@yahoo.com; ihaq@qau.edu.pk

How to cite this article: Nasir B, Fatima H, Ahmed M, Phull A-R, Ihsan-ul-Haq. Cannabis: A Prehistoric Remedy for the Deficits of Existing and Emerging Anticancer Therapies. J Explor Res Pharmacol 2017;2(3):93-104. doi: 10.14218/JERP.2017.00012. chemistry and genetics. ${ }^{11}$ The morphological diversity of this plant is phenomenal, and it has tremendous potential as foodstuff and fuel (edible food/oil from its achene), fibre (stem) and pharmaceuticals. It also has unrivalled biochemical riches with regard to its considerable balance of active and biologically significant compounds and their potential medical uses. ${ }^{12}$

\section{History}

The history of $C$. sativa use dates back to over 10,000 years, supporting its recognition as one of the oldest domestic plants known to humanity. ${ }^{7,13}$ It originated from Central Asia and is one of the oldest known psychotropic drugs. C. sativa was cultivated and consumed long before civilization; therefore, uncovering the origin of its use by humans is a difficult task. Archaeological discoveries have shown that it has been recognized and acknowledged since the Neolithic era in China, (around $4000 \mathrm{BC}$ ). ${ }^{13}$ However the psychoactive potential of this plant was recognized by western medicine quite latter, with the year of 1839 seeing the first of its real description of actions. ${ }^{14}$

China's Emperor Shen Nung wrote in his 2737 BC compendium the first description of the properties and medicinal uses of C. sativa.${ }^{14}$ Subsequently, it was cultivated for its fibre, fuel, seeds and medicinal purposes. ${ }^{11}$ A distinguished surgeon in ancient China, Hua Tuo (115-205 AD), reportedly used cannabis as an anaesthetic. The analgesic and anaesthetic tendencies of $C$. sativa were also revealed in the biography of Chinese physician Hoa-tho, who practiced around $220 \mathrm{AD} .{ }^{15} \mathrm{C}$. sativa then spread to the rest of the world, to ancient Egypt, prehistoric Europe, ancient Greece and Rome, Persia and Arabia, India, South America, Europe and North 


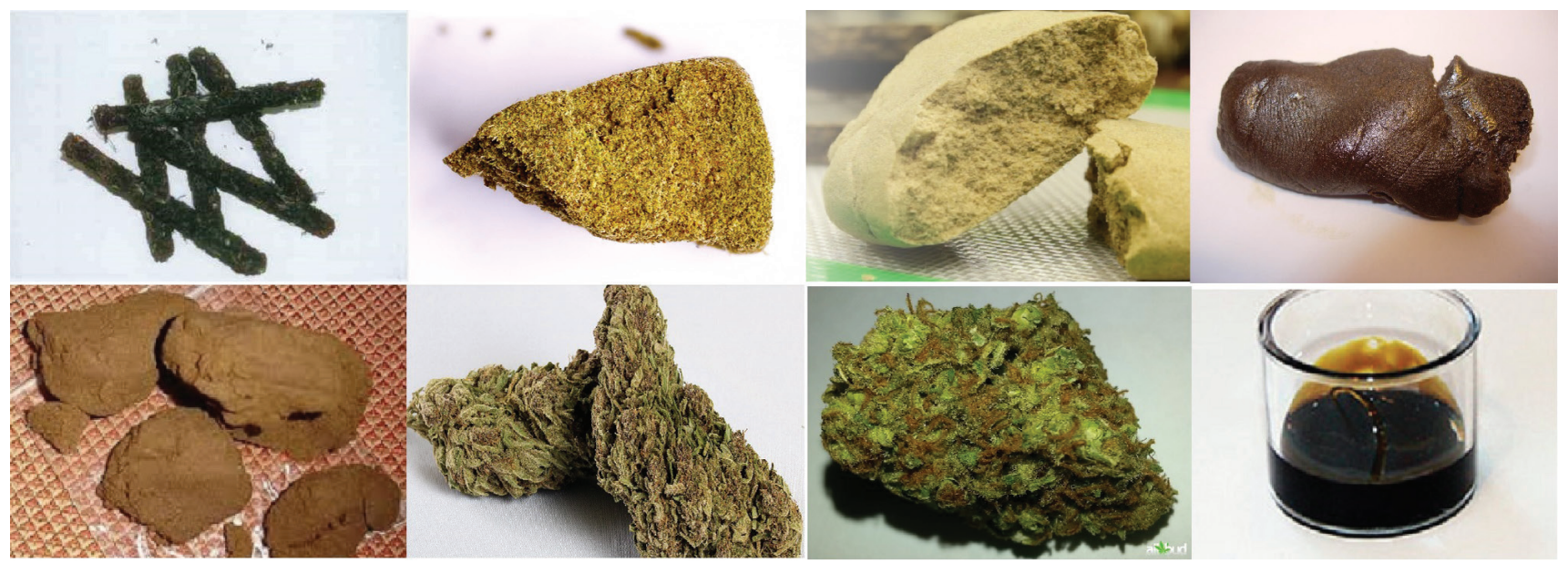

Fig. 1. Cannabis products. First row, left to right: Indian, Lebanese, Turkish and Pakistani hashish. Second row, left to right: Swiss hashish, Zairean marijuana, Swiss marijuana, Moroccan hash oil. Adopted from: https://www.icmag.com/ic/.

America. ${ }^{16}$

\section{Habitat}

C. sativa is a species well-adapted to diverse climates, from plains to altitudes of 10,000 feet. It probably originated from Central Asia and is now distributed widely, enjoying a global reputation. The major pool of cannabis supply is from China, Russia, India, Pakistan and Iran, but it is also cultivated in other parts of the world.

\section{Forms/preparation}

The strong narcotic obtained from the resin of stem, leaves, flower and fruit is predominantly available in three different forms known by their Indian names, 'bhang, ganja and charas'. These preparations vary according to their potency, extraction and administration. Bhang is much weaker than charas or ganja and is actually constituted of a seeded blend of C. sativa flowers, as well as its stem and leaves. Ganja is essentially derived from seedless unfertilized female flowering tops, while charas (hashish in Arabic) is procured through hand rolling or sieving and screening of cannabis trichomes. ${ }^{17}$ All preparations are presented in Figure 1.

\section{Phytochemistry}

The chemical makeup of $C$. sativa is highly complex, due to the wide array of chemical constituents and their possible interactions with each other. These compounds are from diverse chemical classes (e.g., flavonoids, steroids, hydrocarbons, mono and sesquiterpenes, nitrogenous compounds and amino acids). ${ }^{18}$ More than 500 constituents have been identified in $C$. sativa. ${ }^{18-23} \mathrm{C} 21$ terpenophenolic cannabinoids are the most common and extensively studied class of cannabis constituents. The term cannabinoids represents a group of compounds found distinctively in C. sativa. ${ }^{24}$ The introduction of synthetic cannabinoids and discovery of endocannabinoids (endogenous cannabinoids receptor ligands which are chemically different from those isolated from cannabis) has prompted utilization of the word "phytocannabinoids" to describe these compounds. ${ }^{25}$ The number of natural compounds identified in $C$. sativa is continuously increasing; for example, there were 423 in $1980,{ }^{26} 483$ in $1995^{23}$ and more than 525 in $2008 .{ }^{18-23}$ Described below is a brief overview of the phytochemical aspects of C. sativa, with special focus on the psychoactive components (e.g., cannabinoids).

\section{Cannabinoids}

Cannabinoids, along with their analogues and transformation products, are the characteristic carbon 21 group of compounds found in C. sativa. ${ }^{18}$ The known cannabinoids can be classified into a few main structural types, while the variations amongst them are fairly basic (e.g., presence or absence of a carboxyl group on the phenolic ring, with one of the hydroxyl moieties of the basic structure been replaced by a methoxy group or a methyl, propyl or butyl side chain replacing the pentyl one). These compounds can be categorized into various sub-classes (Fig. 2).

Among these, the first compound to be isolated from resin obtained from marijuana was cannabigerol (CBG). ${ }^{27}$ Besides, another group of compounds named as cannabidiol (CBD), discovered in 1940, has trans-absolute configuration and most probably negative optical rotation. Similarly, cannabicyclol (CBL) are compounds first considered to have structural similarity with trans-tetrahydrocannabinol (-THC) type compounds ${ }^{28}$ but later were confirmed to represent a different class, on the basis of results obtained via nuclear magnetic resonance and X-ray analysis. ${ }^{29-31}$ A few miscellaneous types of cannabinoids have also been reported, and these include terpenoids, flavonoids, carbohydrates, fatty acids, hydrocarbons, simple alcohols, aldehydes, ketones, acids, esters and lactones. ${ }^{32}$ Structures of the various cannabinoids are presented in Figure 3.

\section{Pharmacology of cannabinoids}

\section{Cannabinoid receptors}

The G protein-coupled receptors associated with the endocannabi- 


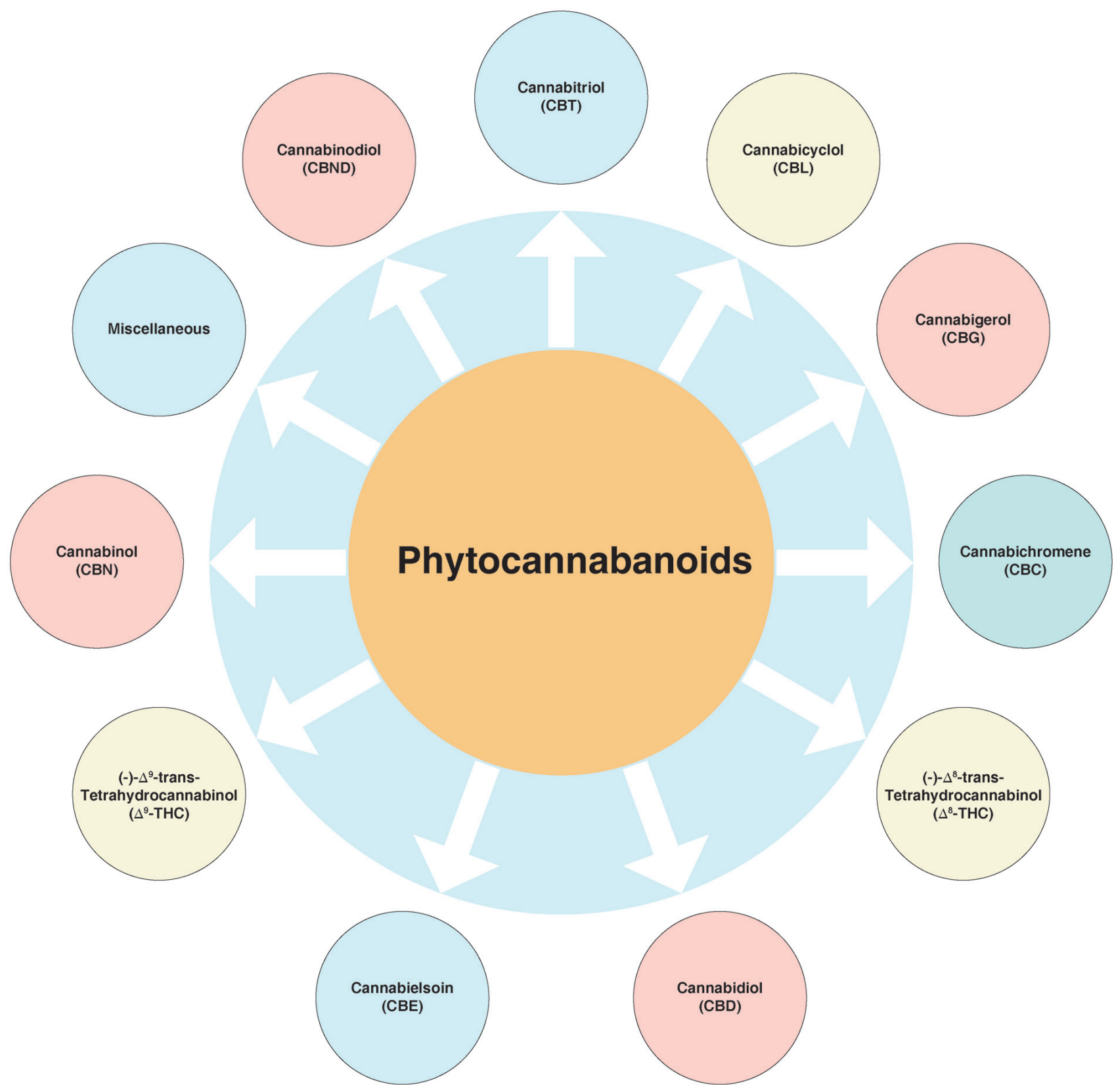

Fig. 2. Various classes of cannabinoids isolated from C. sativa.

noid signalling system mediate actions of cannabinoids, namely the cannabinoids receptor type 1 (CB1) and type 2 (CB2). Activation of any of the aforementioned receptors leads to diminished cyclic adenosine monophosphate levels intracellularly, coupled with activation of phosphoinositide 3-kinase and mitogen-activated protein kinase pathways. ${ }^{33}$

The central and peripheral arms of the nervous system are known to possess the maximum concentration of CB1 receptors, with basal ganglia, cortex, olfactory lobes, hippocampus, spinal cord and cerebellum showing highest receptor densities. The presence of CB1 receptors at these areas accounts for the pharmacological effects of cannabinoids on movement, cognition, memory and emotions. Nociceptive transmission is mediated by the CB1 receptors located in the spinal cord, predominantly in its peri-aqueductal grey matter and dorsal horn. These receptors are very few in the brainstem, justifying the fact that respiratory depression is absent after administration of cannabinoids.

CB2 receptors are found peripherally and they are in close connection with cells in the immune system, particularly the macrophages and spleen, wherein they contribute to regulation of the immune system through meditated release of cytokines. These receptors are not allied with psychoactive effects. Another phytocannabinoid, CBD employs anti-inflammatory effects via stimulation of transient receptor potential vanillin (TRPV) channel proteins and inhibition of cyclooxygenase enzymes 1 and 2 respectively. ${ }^{34}$ 


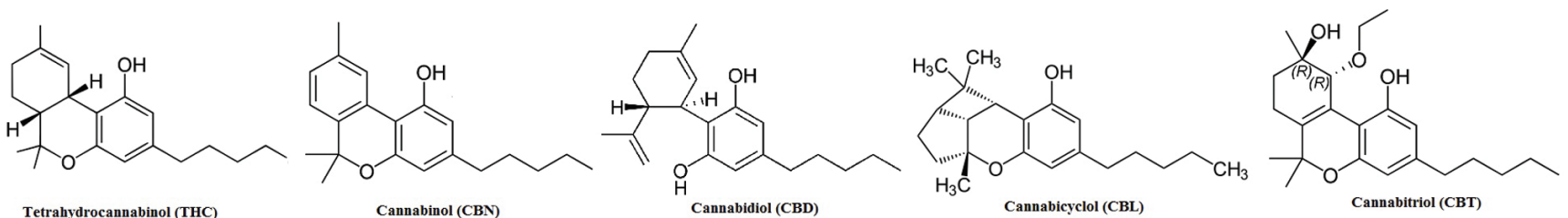

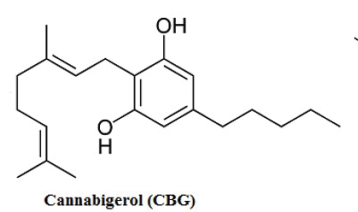<smiles>CCCCCc1cc(O)c2c(c1)OC(C)(CCC=C(C)C)C=C2</smiles>
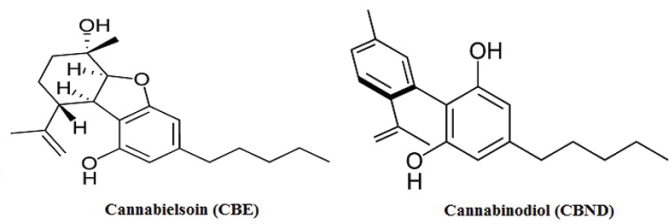

Fig. 3. Structures of various cannabinoids isolated from $C$. sativa and their derivatives.

\section{Pharmacokinetics}

The two most common routes for the intake of natural as well as synthetic cannabinoids include the inhalation and oral routes, although other routes are also available. A number of factors influence the concentration of THC present in its natural preparation, including plant variety, type of preparation (hash oil $>$ hash $>$ sinsemilla [seedless plant] $>$ smoked or ingested leaves and flowers) and the technique of cultivation. ${ }^{35}$ All the cannabinoids are absorbed swiftly when administered through the inhalation route, taking 15 min to achieve their maximum brain concentration.

Absorption seems to be variable depending upon the route of administration. After oral administration, THC undergoes firstpass hepatic metabolism, which leads to generation of its psychoactive metabolite (i.e. 11-hydroxy $\Delta^{9}$-THC). Cannabinoids can cross the placenta, enter the foetal circulation and may pass into breast milk. ${ }^{34}$ Cannabinoids are also greatly lipid soluble, so they accumulate in fatty tissues and are released slowly into the circulating blood. Because of this accumulation, elimination from the body is very slow and may take several days.

Cannabinoids are metabolised primarily in the liver by the CYP2 C subfamily, and a large inter-individual difference exists in the metabolizing capabilities of cannabinoids. Therefore, the rate of metabolism is slowed down in case of liver disease. 11-hydroxy$\left(\Delta^{9}\right.$-THC), which is the chief metabolite and more potent than $\Delta^{9}$ THC, may be responsible for some of the characteristic effects of cannabis. THC is predominantly eliminated in the faeces and to a less extent in the urine. ${ }^{25,34}$

\section{Cannabinoids as medicine/anticancer agents}

C. sativa has been known for its euphoric and psychoactive effects, but limited research has been done on its possible pharmaceutical application. Studies exploring the pharmacological potential of this plant were provoked by the isolation of its main psychoactive component (i.e. THC). ${ }^{36}$ Thus far, cannabinoids have been used efficiently in the treatment of nausea, vomiting, lack of appetite and pain, ${ }^{37}$ representing the side effects most usually manifested in cancer patients during chemotherapy. Cannabinoid use in oncology is somehow underrated, since studies reporting the growth inhibitory action of various cannabinoids on different cancer cell types have grown in number.

The first study that reported the antitumor effects of cannabinoids was done in $1975 .{ }^{38}$ In vitro and in vivo inhibition (mice) of Lewis lung adenocarcinoma cell growth was demonstrated by the administration of $\Delta^{9}$-THC, $\Delta^{8}-$ THC and CBN. Since then, the anti-angiogenic, antimetastatic, antiproliferative and pro-apoptotic effects of cannabinoids have been shown in various cancer types (e.g., lung, glioma, skin, thyroid, lymphoma, skin, pancreas, uterus, breast and prostate carcinoma) using both in vitro and in vivo models. ${ }^{39-43}$

A promising area of study for the therapeutic applications of cannabinoids has been their antitumor activity against a variety of aggressive cancers. ${ }^{44}$ Table $1^{38-41,45-59}$ shows the types of tumours that are sensitive to growth inhibition induced by cannabinoids. Other in vitro studies have also suggested that THC and other naturally occurring cannabinoids have antineoplastic effects

Table 1. Cannabinoids action against various tumours

\begin{tabular}{|c|c|c|c|}
\hline Type & Study model & Action & [Reference] \\
\hline Breast carcinoma & In vitro & Cell cycle arrest & {$[47,55,56]$} \\
\hline Colorectal carcinoma & In vivo (mouse); in vitro & Apoptosis; reduced cell proliferation & {$[45,50-52]$} \\
\hline Glioma & In vivo (mouse, rat); in vitro & Decreased tumour size; apoptosis & {$[39,40,49,57]$} \\
\hline Lung carcinoma & In vivo (mouse); in vitro & Decreased tumour size; inhibition of cell growth & [38] \\
\hline Lymphoma & In vivo (mouse); in vitro & Decreased tumour size; apoptosis & {$[53]$} \\
\hline Neuroblastoma & In vitro & Apoptosis & {$[48,49]$} \\
\hline Skin carcinoma & In vivo (mouse); in vitro & Decreased tumour size; apoptosis & {$[41]$} \\
\hline Prostate carcinoma & In vitro & Apoptosis & {$[46,47,54]$} \\
\hline Uterus carcinoma & In vitro & Inhibition of cell growth & {$[58,59]$} \\
\hline
\end{tabular}




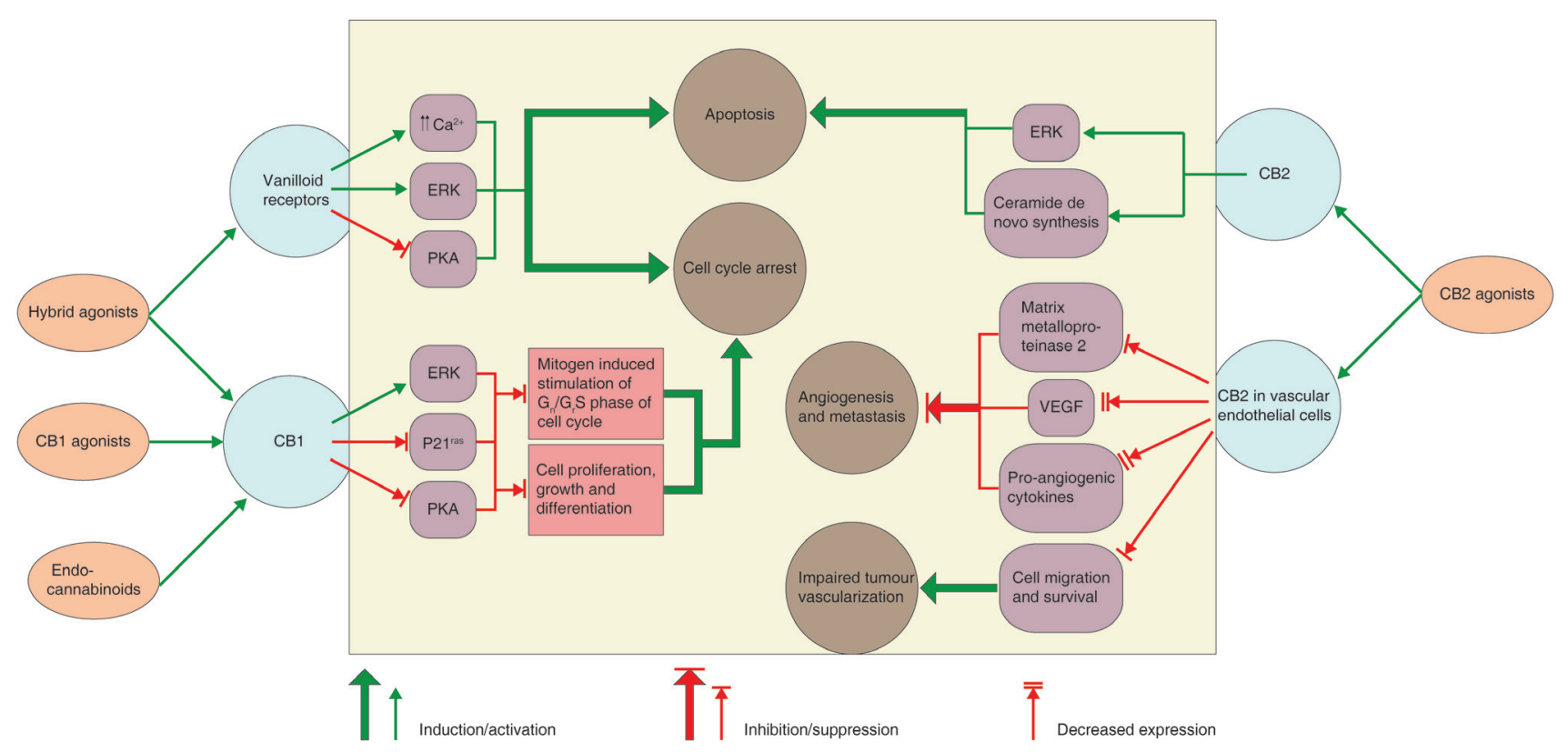

Fig. 4. Cannabinoid receptors, intracellular signals and mechanisms of the anticancer action of cannabinoids/cannabimimetics. Cannabinoids receptor type 1 (CB1) activation in human breast and prostate cancer cells signal in various intracellular pathways which have a role in control of cell fate. The apoptotic action of cannabinoids on glioma cells rely on de novo ceramide generation and extracellular signal-regulated kinase (ERK) activation. Cannabinoid action on cannabinoids receptor type 2 (CB2) in vascular endothelial cells tends to block the angiogenic process and metastasis in mouse models of glioma and skin carcinoma. The figure is a simplified version and crosstalk between different pathways has been omitted. (PKA, protein kinase A; p21 ras K-ras oncogene product; VEGF, vascular endothelial growth factor). ${ }^{60,71}$

against breast cancer, gliomas, lung carcinomas, lymphomas, neuroblastoma, colorectal carcinoma (CRC), skin carcinomas, prostate carcinoma and uterine carcinoma. ${ }^{45,60}$ Antineoplastic effects of naturally occurring cannabinoids have also been shown through various in vivo studies involving mice having xenografts of lung and skin carcinomas, lymphomas and gliomas. ${ }^{39,60}$

\section{Mechanism of anticancer action}

The roles of cannabinoid receptors in mediating the anticancer action of cannabinoids have been advocated by expression studies and by the inhibitory action of cannabinoid antagonists. It has also been found that $\mathrm{CB} 2$ plays a more important role than $\mathrm{CB} 1$ in bringing about the anticancer activity of cannabinoids. ${ }^{46}$ Also, the concentration of cannabinoid receptors on tumour cells has been found to be much higher than on the corresponding normal tissue in different cancer types. For instance, CB2 expression in human epidermal growth factor receptor-2 (HER2)-positive breast cancer is significantly higher $(91 \%)$ than in HER2-negative breast cancers $(35-72 \%)$ and normal breast tissue $(5 \%){ }^{61,62}$

Furthermore, cannabinoids may cause selective growth inhibition in tumour cells while sparing normal tissue..$^{63,64}$ For example, cannabinoid exposure causes ceramide-induced cell death in glioma cells, whereas the same cannabinoid-mediated mechanism is responsible for the protection of astrocytes from oxidative stress. ${ }^{64}$ The antitumor effects of cannabinoids can be mediated by their action on either $\mathrm{CB} 1{ }^{46,47,65,66}$ or CB2 receptors or both, ${ }^{40,41,67}$ and on TRPV1 receptors in the case of endocannabinoid anandamide. ${ }^{48,68,69}$ The association between expression of CB1 and/or CB2 receptors and prognosis has also been reported for several tumour types. ${ }^{70}$

Despite the data presented by numerous authors, the exact mechanism of the antitumor action of these molecules has not been fully characterized. Furthermore, the mechanisms of action

Table 2. Mechanism of action and intracellular signals involved in the anticancer action of cannabinoids ${ }^{60,71}$

\begin{tabular}{|c|c|c|}
\hline Cannabinoids/Cannabimimetics & Mechanism of action & Intracellular signals \\
\hline CB1 agonists & $\begin{array}{l}\text { Inhibition of the mitogen-induced } \\
\text { stimulation of } G_{0} / G_{1}-S \text { phase of cell cycle }\end{array}$ & $\begin{array}{l}\text { Extracellular signal-regulated kinase (ERK) } \\
\text { activation; suppression of p } 21^{\text {ras }} \text { activity; } \\
\text { protein kinase } A(P K A) \text { inhibition }\end{array}$ \\
\hline CB2 agonists & Induction of apoptosis & $\begin{array}{l}\text { ERK activation; sustained ceramide generation } \\
\text { through elevated de novo synthesis }\end{array}$ \\
\hline Endocannabinoids & $\begin{array}{l}\text { Inhibition of the mitogen-induced } \\
\text { stimulation of } G_{0} / G_{1}-S \text { phase of cell cycle }\end{array}$ & ERK activation; obstruction/inhibition of $\mathrm{p} 21^{\text {ras }}$ activity \\
\hline $\begin{array}{l}\text { CB1/vanilloid receptor } \\
\text { 'hybrid' agonists }\end{array}$ & $\begin{array}{l}\text { Inhibition of the mitogen-induced } \\
\text { stimulation of } G_{0} / G_{1}-S \text { phase of cell } \\
\text { cycle; induction of apoptosis }\end{array}$ & $\begin{array}{l}\text { PKA suppression; ERK activation; vigorous/ } \\
\text { strong elevation in } \mathrm{Ca}^{2+} \text { level }\end{array}$ \\
\hline
\end{tabular}


of these molecules vary according to the various tumour cell type under examination. Review of various studies has indicated that cannabinoids can act via diverse cellular mechanisms (Fig. $4^{60,71}$ ), and the mechanism may involve induction of apoptosis and/or autophagy, suppression of cell signalling pathways working in cell proliferation, cell growth inhibition or cell cycle arrest, but it may also include targeting of angiogenesis and cell migration. ${ }^{60,63,71-73}$

The possible mechanisms and intracellular signals involved in the anticancer action of cannabinoids are summarized in Table $2^{60,71}$.

\section{Cannabinoids in treatment of cancer}

\section{Brain cancer}

Clinical management of malignant gliomas is an important research area. Gliomas represent the most common form of brain tumour, are associated with an adverse prognosis and unresponsiveness to treatment. Natural and synthetic cannabinoids, as well as those found endogenously, have been reported to affect the cell proliferation rate in cell lines derived from the central nervous system. A study demonstrated that THC and WIN-55,212-2 (a mixed CB1/CB2 agonist) stifled the growth of rat glioma C6 cells inoculated intra-cerebrally (rat) or subcutaneously (mice), with the mechanism of action being based in activation of cannabinoid receptors. ${ }^{39,49,74}$

In another study that aimed to determine the possible in vitro antiproliferative effect of CBD, a non-psychoactive cannabinoid, two glioma cell lines of human origin were used (U87 and U373). A significant decrease in viability and mitochondrial oxidative metabolism was observed in the glioma cells, in a concentrationdependent manner with an apparent $\mathrm{IC}_{50}$ of $25 \mu \mathrm{M}$. The antiproliferative effect of CBD was also shown to be correlated to induction of apoptosis. The significant antitumor activity of CBD suggested its possible application as an antineoplastic agent. ${ }^{75}$

Torres et al. $^{76}$ examined the combined effect of $\Delta^{9}$-THC and temozolomide (TMZ) in the treatment of glioblastoma multiforme. A significant antitumor action in glioma xenografts was observed. Moreover, tumours that are resistant to TMZ treatment were also shown to be responsive to the combination. This formulation also increased the autophagy and the mechanism was confirmed by pharmacological or genetic inhibition of this process, which resulted in the prevention of cell death. Likewise, a fair safety profile and antiproliferative action of $\Delta^{9}$-THC on tumour cells was reported in its phase 1 clinical trial in 9 patients with recurrent glioblastoma multiforme. ${ }^{77}$

When comparison of CB2 receptor expression in paraffinembedded sections from primary brain tumours of paediatric and adult patients was made, their expression was found to be high in most glioblastomas and to correlate with tumour grade. High CB2 immunoreactivity was also observed in some benign paediatric astrocytic tumours, such as subependymal giant cell astrocytoma. Thus, these tumours might be vulnerable to cannabinoid treatment. ${ }^{78}$ Despite a few contradictory reports regarding the mechanism of action of cannabinoids, these studies offer exciting new dimensions in the treatment of brain cancers.

\section{Breast cancer}

About $30 \%$ of newly diagnosed cancers each year are breast cancer cases, and the ErbB2 tyrosine kinase receptor is over expressed in almost one-third of them (Her2 in humans, Neu in rats). ${ }^{79}$ ErbB2positive cancer characterizes highly aggressive phenotypes and such tumours are often described by their reduced responsiveness to standard treatment plans. To determine the potential of cannabinoids as a new therapeutic choice in the management of ErbB2positive breast tumours a study was conducted by which their antitumor potential was examined in a clinically relevant model of ErbB2-driven metastatic breast cancer (the MMTV-neu mouse). A series of human breast tumours were used to analyse the expression of cannabinoid targets. The results obtained showed that $\Delta^{9}$-THC and non-psychotropic CB2 cannabinoid receptor agonist JWH-133 reduced tumour progression to a significant extent and that these belligerent and less responsive tumours could be effectively treated with these agents. ${ }^{61}$

A group of researchers investigated the antitumor potential of numerous plant cannabinoids (i.e. $\mathrm{CBD}, \mathrm{CBG}, \mathrm{CBC}, \mathrm{CBD}$ acid, and THC acid), and compared the efficacy and advantage of cannabis extracts compared to the use of pure cannabinoids. Amongst the tested compounds, CBD was found to be the most powerful growth inhibitor in cancer cells, with $\mathrm{IC}_{50}$ values between 6.0 and $10.6 \mu \mathrm{M}$. The researchers concluded that $\mathrm{CBD}$ and cannabis extract enriched in this natural cannabinoid may serve as an encouraging choice in non-psychoactive antineoplastic strategy. It inhibited cell growth as well as tumour metastasis, particularly in the case of a highly malignant human breast carcinoma cell line. The mechanism of antineoplastic action of CBD in human breast carcinoma included activation of CB2 and TRPV1 receptors and initiation of oxidative stress, all of which contribute to apoptosis induction. ${ }^{80}$

In another study, the down-regulation of Id-1 in aggressive human breast cancer cells was reported with CBD and to occur in a dose-dependent fashion. ${ }^{81}$ Basic helix-loop-helix transcription factors are negatively regulated by Id- $1 .{ }^{82}$ There is strong evidence to suggest that Id-1 controls cellular processes related to tumour progression. ${ }^{83}$ A study in which Id-1 was reduced showed marked decline in proliferation and invasiveness of breast cancer cells in vitro ${ }^{84} \mathrm{CBD}$, therefore, offers a novel nontoxic exogenous choice, effectively decreasing Id-1 expression in metastatic breast cancer cells and rendering the tumour less aggressive. ${ }^{81}$

In a different study intended to discover a compound that could efficiently co-target different antitumor pathways associated with $\Delta^{9}$-THC and CBD, screening for different analogues was done and around 40 resorcinol derivatives were selected for examination owing to their structural similarity with CBD. The compound O-1663 was found to be the most potent of all the tested derivatives in inhibiting breast cancer cell proliferation and invasion in culture and metastasis in vivo. The study suggested the potential use of cannabinoids in the treatment of patients with metastatic breast cancer, and proposed a framework for using these lead compounds for the synthesis of novel cannabinoid analogs ${ }^{85}$ Likewise, another research group reported that $\Delta^{9}$-THC blocked cell cycle progression and induced apoptosis, thereby reducing human breast cancer cell proliferation. They also reported that these effects were produced via activation of $\mathrm{CB} 2$ cannabinoid receptors. The $\Delta^{9}$ THC caused down-regulation of $\mathrm{Cdc} 2$, arresting cells particularly in G2-M phase. Normal human mammary epithelial cells, in terms of their proliferation pattern, were less affected by the cannabinoid used, which is quite encouraging; these findings may lead to an innovative approach for the treatment of breast cancer. ${ }^{86}$

\section{Colon cancer}

CRC, also known as bowel cancer, is regarded as the third most common cancer worldwide both in men and women, with 50,830 deaths and 142,820 new cases estimated to have occurred in $2013 .{ }^{87}$ A trend of steadily rising treatment costs associated with CRC has 
been shown by pharmacoeconomic studies and surveys, which is due to the increasing use of targeted biological therapies. ${ }^{88}$

CBG is a safe and non-psychotropic cannabinoid and interacts with specific targets involved in carcinogenesis. The effect of CBG against colon tumorigenesis was investigated by a group of researchers; mouse models of colon cancer were employed to assess the in vivo antineoplastic effect of CBG. The study revealed growth inhibition of CRC cells by $\mathrm{CBG}$, occurring largely through a pro-apoptotic mechanism. The in vivo growth and development of colon carcinogenesis was also retarded. The inhibitory role of $\mathrm{CBG}$ in tumoural cell growth has a close association to reactive oxygen species overproduction. Notably, the action against CRC cells was rather selective. CBG was hypothesized to be a worthy anti-CRC curative and preventive therapeutic agent, keeping in line with the safety profile of Cannabis-derived cannabinoids..$^{45}$

In another study, CBD was investigated for its possible chemopreventive effect in an experimental model of colon cancer and its likely mechanism of action evaluated in CRC cell lines. The azoxymethane (AOM)-induced colon cancer mouse model was used to study the effect. The effects of AOM treatment were aberrant crypt foci (ACF), tumour and polyp formation, phospho-Akt, iNOS and COX-2 up-regulation, and caspase-3 down-regulation. CBD impeded AOM-induced phospho-Akt and caspase- 3 changes and reduced ACF, polyps and tumours, while in CRC cell lines it prevented oxidative damage of DNA, diminished cell proliferation in a CB1, PPAR $\gamma$ and TRPV1 antagonists sensitive manner, it also elevated endocannabinoid levels. It was concluded from the findings that $\mathrm{CBD}$ exerts an in vivo chemopreventive effect and retards cell proliferation via numerous mechanisms worthy of clinical consideration in colon cancer prevention. ${ }^{50}$

A study conducted on CRC investigated related expression and the underlying molecular mechanism of apoptotic activity associated with $\mathrm{CB} 1$ and $\mathrm{CB} 2$ up-regulation. The receptor expression was studied in cell lines of colon cancer (DLD-1 and HT29) as well as human cancer specimens. CB1 expression was found to be high in normal human colonic epithelium, while CB2 expression was significantly high in tumour tissue. Activation of these receptors, especially CB2 triggered apoptosis and elevated ceramide level in the cell lines investigated. Pharmacologic inhibition of new ceramide synthesis inhibited apoptosis. Ceramide upsurge and consequent apoptosis initiated by cannabinoid receptor activation was abrogated by the knockdown of TNF- $\alpha$ mRNA. The study's authors concluded that apoptosis was induced through ceramide de novo synthesis in colon cancer cells via activation of either the $\mathrm{CB} 1$ or $\mathrm{CB} 2$ receptor. $\mathrm{TNF}-\alpha$ was determined to primarily serve as a link between activation of cannabinoid receptors and ceramide production. ${ }^{51}$

In another study, CBD-rich $C$. sativa extract was tested for its possible effect on healthy colonic and CRC cell proliferation (using DLD-1 and HCT116 cell lines), while the in vivo effect was estimated using experimental models of colon cancer. The results showed that proliferation in tumour cells was reduced by CBD, but it did not show a similar response in normal cells. AOM-induced polyps, preneoplastic lesions and tumour progression in a xenograft model of colon cancer was reduced by $\mathrm{CBD}$ in vivo. It was, thus, concluded that $\mathrm{CB} 1$ and $\mathrm{CB} 2$ receptor activation by $\mathrm{CBD}$ was responsible for attenuation of colon carcinogenesis and inhibition of colorectal cancer cell proliferation. ${ }^{52}$

\section{Liver cancer}

A study conducted to investigate the effects of cannabinoids on growth of hepatocellular carcinoma (HCC) showed that $\Delta^{9}-\mathrm{THC}$ and JWH-015 (a CB2 receptor agonist) via stimulation of CB2 re- ceptors reduced the viability of $\mathrm{HuH}-7$ (HCC cells) and HepG2 (human HCC cell line). The investigators found that $\Delta^{9}$-THC and JWH-015 promoted human HCC death via induction of autophagy, both in cell culture and xenografted mice experimental systems. Those study results might well help in designing novel therapeutic strategies for the management of $\mathrm{HCC} .{ }^{89}$

\section{Lung cancer}

Survival rate in lung cancer patients is low, leading to a demand for design of new approaches that will allow for better management of the disease. Cannabinoid-based antitumor therapies represent new strategies and many studies have reported their antiproliferative potential. The first study to show that oral administration of $\Delta^{9}$-THC can retard the growth of Lewis lung adenocarcinoma also indicated that the mechanism of these effects involved DNA synthesis inhibition. ${ }^{60}$ Another study showed that $\Delta^{9}$-THC caused inhibition of epidermal growth factor-induced phosphorylation of ERK1/2, c-Jun-NH2-kinase1/2, and Akt in the A549 human lung cancer cell line. Moreover, when studied in vivo, it resulted in suppression of subcutaneous tumour growth and metastasis in severely immunodeficient mice. ${ }^{90}$

\section{Lymphoma}

Numerous studies have reported on the antitumor potential of cannabinoids in various lymphoma tumours. Lymphoma tumours EL-4, LSA and P815, when exposed in vitro to $\Delta^{9}$-THC, showed increased apoptosis and significantly reduced cell viability; moreover, the $\Delta^{9}$-THC administration to EL-4 tumour-bearing mice reduced tumour load significantly, potentiated apoptosis in tumour cells and, likewise, the survival of tumour-bearing mice. ${ }^{91}$ In another study, cannabinoid receptor ligands (anandamide and WIN$55,212-2$ ) were used to treat mantle cell lymphoma (MCL), with a resultant decrease in cell viability. ${ }^{92}$ Cannabinoid receptor-mediated apoptosis was shown to be induced by (R)-methanandamide and WIN-55,212-2 in MCL. These studies propose that CB1 and $\mathrm{CB} 2$ receptors might be targeted by cannabinoids and/or their agonists, taking the field one step further in the quest towards finding new therapeutic strategies for the treatment of lymphoma. ${ }^{93}$

Another research group reported expression of CB2 receptors after examination of numerous human leukaemia and lymphoma cell lines, including Jurkat, Molt-4 and Sup-T1. These cell lines showed susceptibility to apoptosis induced by $\Delta^{9}-\mathrm{THC}, \mathrm{HU}-210$ (a synthetic cannabinoid), anandamide (endogenous cannabinoid) and CB2 receptor agonist JWH-015. $\Delta^{9}$-THC also induced apoptosis and reduced cell viability in primary acute lymphoblastic leukaemia cell culture. The results suggest that $\mathrm{CB} 2$ receptors may represent possible targets for apoptosis induction and that selective CB2 agonists bearing minimal or no psychotropic effects may serve as novel anticancer agents. ${ }^{53}$

\section{Pancreatic cancer}

Pancreatic cancer is classified as one of the most fatal cancer types. Cannabinoid exposure has been shown to cause apoptosis of pancreatic tumour cells, and this effect was found to rely on $\mathrm{CB} 2$ receptor and ceramide-dependent up-regulation of the stress regulation protein $\mathrm{p} 8$ and ATF-4 and TRB3 stress-related genes. ${ }^{93}$ However, to identify the true potential of cannabinoid-based therapy for the management of pancreatic cancer, detailed studies are a 
Table 3. Cannabinoid analogy and cannabinoid receptor ligands

\begin{tabular}{|c|c|c|c|c|}
\hline S. No & Compound & Chemistry & Pharmacology & [Reference] \\
\hline 1 & Anandamide & Endogenous cannabinoid & MCL, Prostate cancer & {$[46,92]$} \\
\hline 2 & HU-210 & Synthetic cannabinoid & Leukaemia, lymphoma & {$[53]$} \\
\hline 3 & HU-331 & Synthetic cannabinoid (quninone synthesized from CBD) & colon carcinoma & {$[95]$} \\
\hline 3 & JWH-015 & Synthetic $\mathrm{CB} 2$ receptor agonist & Leukaemia, lymphoma, HCC & {$[89,53]$} \\
\hline 4 & JWH-133 & Synthetic $\mathrm{CB} 2$ receptor agonist & ErbB2-positive breast tumours & {$[61]$} \\
\hline 5 & Methanandamide & Synthetic endocannabinoid analogy & Lymphoma & [93] \\
\hline 6 & $0-1663$ & Synthetic cannabinoid & Breast cancer & {$[85]$} \\
\hline 7 & WIN-55-212-2 & Synthetic cannabinoid (full CB1 agonist) & Glioma, MCL, prostate cancer & {$[75,92,94]$} \\
\hline
\end{tabular}

prerequisite to determine the mechanism of cell death induced by these compounds.

\section{Prostate cancer}

Prostate cancer is amongst the most prevalent cancers diagnosed in men, and it has been quite a challenge to develop novel therapeutic strategies for its management. A study aimed at developing new targets for the treatment of prostate cancer showed significantly higher expression levels of $\mathrm{CB} 1$ and $\mathrm{CB} 2$ in cells derived from adenocarcinoma of human prostate tissue (CA-human papilloma virus-10), as well as some other human prostate cells (LNCaP, CWR22RN1, DUI45 and PC3) as compared to cells derived from normal human prostate tissue (PZ-HPV-7). A dose-and time-reliant cell growth inhibition was observed in $\mathrm{LNCaP}$ cells when treated with WIN-55,212-2, the effect being prevented by CB1 and CB2 receptor antagonists (SR 141716 and SR 144528, respectively). The results suggested the possible development of cannabinoid receptor agonists for the treatment of prostate cancer. ${ }^{94}$

Another study revealed the expression of cannabinoid receptors in prostate tissue and $\mathrm{PC}-3$ cells (human prostate cancer cell line). However, the induction of apoptosis by $\Delta^{9}$-THC treatment was found to occur through a receptor-independent mechanism. ${ }^{54}$
It was also found that the endogenous cannabinoid anandamide possesses antiproliferative and apoptotic effects in human prostate cancer cell lines (LNCaP, DU145 and PC3); the effects of which being mediated by epidermal growth factor receptor (EGFR) down-regulation and ceramide accumulation. ${ }^{46}$ Various cannabinoid analogues and various cannabinoid receptor ligands are listed in Table $3,46,53,61,75,85,89,92-95$ along with their pharmacological actions. Structures of the cannabinoid analogues and synthetic cannabinoids are presented in Figure 5.

\section{Cannabinoids in cancer palliation}

Cannabinoids were used for the palliative treatment of cancer long before its medicinal use in oncology was recognized. ${ }^{39}$ Rather than treating the underlying cause of cancer, they were primarily used for the relief of symptoms associated with cancer. ${ }^{96}$ The palliative use of cannabinoids in cancer include its uses as an antiemetic, ${ }^{97-100}$ analgesic ${ }^{101-103}$ and appetite stimulant. ${ }^{104}$

\section{Limitations and possibilities}

The possible use of THC in oncology might be accompanied by<smiles>CCCCCCC(C)(C)c1cc(O)c2c(c1)OC(C)(C)[C@H]1CC=C(CO)C[C@H]21</smiles>

HU-210<smiles>CCCCC/C=C\C/C=C\C/C=C\C=C/CCCC(=O)NCCO</smiles>

Anandamide<smiles>CCCCCc1cc(OC(C)=O)c2c(c1)OC(C)(C)C1CCC(C)=CC21</smiles>

$0-1663$<smiles>Cc1c(C(=O)c2cccc3ccccc23)c2cccc3c2n1[C@@H](CN1CCOCC1)CO3</smiles>

WIN-55,212-2<smiles></smiles>

JWH-015<smiles>CCCC(C)(C)c1ccc2c(c1)OC(C)[C@@H]1CC=C(C)C[C@H]21</smiles>

JWH-133<smiles>CCCCC/C=C\C/C=C\C/C=C\C/C=C\CCCC(=O)N[C@@H](C)CO</smiles>

Methanandamide

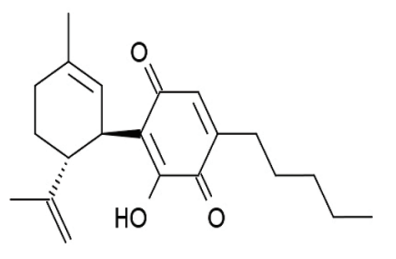

HU-331

Fig. 5. Structures of various cannabinoid analogues. 
certain limitations, especially its side effects at the central nervous system level, which include hallucinations, somnolence, dysphoria, abnormalities in thoughts and perception, and depersonalization. ${ }^{105}$ On the contrary, direct psychotropic proprieties are not usually reported in cases of most non-THC plant cannabinoids, particularly for $\mathrm{CBD} .{ }^{106,107} \mathrm{CBD}$ even blocks the conversion of THC to the more psychoactive 11-hydroxy-THC, thus mitigating its psychoactivity. ${ }^{108,109}$ Furthermore, it has been reported that the response to marijuana, whether neurophysiological or behavioural, is not affected by the systematic variations in its constituents (i.e. $\mathrm{CBD}$ and $\mathrm{CBC}){ }^{110}$ Numerous such observations and studies have strengthened the concept of promoting non-psychoactive cannabinoids as potential anticancer agents. Their development, therefore, will demand more advanced studies focusing on the underlying anticancer mechanisms as well as the pros and cons of their possible use in treating different cancer types.

A perplexing situation has arisen from reports of the cancer cell growth-stimulating properties of cannabinoids at low doses in vitro. ${ }^{90}$ The role of proteins is of great importance and in some instances their dual roles make them a double-edged sword. Studies have shown that there are numerous proteins capable of existing in more than one subcellular location. Moreover, additional activities have been reported for identical proteins found in different locations within the cell. Such differential localization profiles may be illustrative of a new mechanism through which cells can exploit a partial sum of genomic information to elicit complex behavioural and biological phenotypes.

Cancer prognosis can be negatively affected by dysregulation of translocation. Proteins exhibiting multiple, independent functions (other than those already identified) are designated as "moonlighting proteins". Apart from change in cellular localization, the functions of such moonlighting proteins can vary based on changes in redox state of cell, oligomeric state of the protein, and temperature or variations in cellular concentration of a substrate, ligand, cofactor or product. ${ }^{111}$ The target proteins of different cancers have been identified as moonlighting proteins owing to their ability to accomplish mechanistically discrete functions.

Proteins with dual characteristics relevant to anticancer action of cannabinoids include the following: ERK, c-Jun, and Akt in lung cancer; ATF4 and TBR3 in pancreatic cancer; and EGFR in prostate cancer. ${ }^{112-115}$ Thus, the critical review and rationalization of understanding related to protein functions in cancer pathways is of primary importance. Notwithstanding the fact that the observed effects of cannabinoids are multifaceted, complicated and contradictory in some instances, formidable evidence exists to advocate that cannabinoids might present useful alternatives in our pursuit for new chemotherapeutic agents. ${ }^{42,43,80,93,116,117}$

\section{Future research direction}

Development of new anticancer therapies is the need of the hour; however, their introduction to and potential application in clinic should be made with great caution and systematically. The anticancer value of this ancient remedy can only be fully exploited if future research is directed towards drawing a realistic correlation between the significant in vitro findings and results obtained from clinical trials run in parallel.

A decent safety profile and palliative effects of cannabinoids in cancer patients make them useful candidates for clinical trials. The anticancer mechanism of bioactive principles from C. sativa can be better understood if further research is performed on molecular level explaining the cellular pathways involved in the anticancer effects of cannabinoids. Moreover, a deep understanding of the multiple functions of some proteins involved in these pathways can also help in optimizing the use of cannabinoids as potential anticancer agents.

\section{Conclusions}

C. sativa has been known for its psychoactive activity attributed to the exclusive presence of cannabinoids. Identification of cannabinoid receptors has triggered researchers to validate the underexplored pharmacological prospects of this prehistoric remedy. These efforts have provided momentous evidence of the promise of cannabinoids in the quest for the treatment of numerous neoplastic brutalities involving brain, breast, colon, liver, pancreas, lung, blood and prostate, among others. Psychoactive effects associated with cannabis utilization pose serious hurdles against its therapeutic application, so that extensive research is required in standardization of its pharmacokinetic parameters. In order to identify the real potential of cannabinoid-based therapeutics and their anticancer mechanism for the management of various types of cancer, detailed clinical studies are still a prerequisite to ascertaining their safe utility as anticancer agents.

\section{Acknowledgments}

The authors are grateful to the Pakistan Scientific and Technological Information Center (PASTIC) and Higher Education Commission of Pakistan (HEC) for providing free access to its database and the relevant literature. We would also like to acknowledge Mr. Ibrahim Shah, PhD scholar, University of Reading, UK, for his insights and comments on an earlier version of the manuscript. No funds of any sort or magnitude were availed from any organization or institute.

\section{Conflict of interest}

The authors have no conflict of interests related to this publication.

\section{Author contributions}

Compiling the data (BN, HF, MA), designing and writing the manuscript (BN, HF, MA), providing intellectual insights in understanding the anticancer cellular pathways and overall explanation of the pathways (ARP), providing guidance at every step of writing and compilation of the manuscript (IUH), revising and refining all the data provided in the paper (IUH).

\section{References}

[1] McPartland JM, Guy GW. The evolution of cannabis and coevolution with the cannabinoid receptor-a hypothesis. The Medicinal Use of Cannabis and Cannabinoids 2004:71-101.

[2] Miller NG. Miller, genera of cannabaceae 185. Journal of the Arnold Arboretum 1970:185.

[3] Wu Z, Raven P, Hong D. Flora of China. Science Press, Beijing, China 2003;5:234-236.

[4] Anderson LC. A study of systematic wood anatomy in cannabis. Bot Mus Leafl Harv Univ 1974;24(2):29-36.

[5] Anderson LC. Leaf variation among cannabis species from a controlled garden. Bot Mus Leafl Harv Univ 1980;28(1):61-69. 
[6] Emboden WA. Cannabis-a polytypic genus. Echono Bot 1974; 28(3):304-310.

[7] Schultes RE, Klein WM, Plowman T, Lockwood TE. Cannabis: An example of taxonomic neglect. Bot Mus Leafl Harv Univ 1974;23(9):337-367.

[8] Hillig KW. A chemotaxonomic analysis of terpenoid variation in cannabis. Biochem Sys Ecol 2004;32(10):875-891. doi:10.1016/j. bse.2004.04.004

[9] Hillig KW. Genetic evidence for speciation in cannabis (cannabaceae). Genet Resour Crop Evol 2005;52(2):161-180. doi:10.1007/ s10722-003-4452-y.

[10] Hillig KW, Mahlberg PG. A chemotaxonomic analysis of cannabinoid variation in cannabis (cannabaceae). Am J Bot 2004;91(6):966-975. doi:10.3732/ajb.91.6.966.

[11] Amar MB. Cannabinoids in medicine: A review of their therapeutic potential. J Ethnopharmacol 2006;105(1):1-25. doi:10.1016/j. jep.2006.02.001.

[12] Russo EB. History of cannabis and its preparations in saga, science, and sobriquet. Chem Biodivers 2007;4(8):1614-1648. doi:10.1002/ cbdv.200790144.

[13] Merlin MD. Archaeological evidence for the tradition of psychoactive plant use in the old world. Econ Bot 2003;57(3):295-323. doi:10.1663/0013-0001(2003)057[0295:AEFTTO]2.0.CO;2

[14] Li HL. An archaeological and historical account of cannabis in china. Econ Bot 1973;28(4):437-448.

[15] Wills S. Cannabis use and abuse by man: An historical perspective. In: Cannabis the genus cannabis. Edited by Brown DT. USA: Harwood Academic Publishers; 2003;4:1-3.

[16] Raman A. The cannabis plant: Botany, cultivation and processing for use. In: Cannabis the genus cannabis. Edited by Brown DT. USA: Harwood academic publishers; 2003;4:10-30.

[17] Russo E. Cannabis in india: Ancient lore and modern medicine. In: Cannabinoids as therapeutics. Springer; 2005:1-22. doi:10.1007/37643-7358-X_1.

[18] ElSohly MA, Slade D. Chemical constituents of marijuana: The complex mixture of natural cannabinoids. Life Sci 2005;78(5):539-548. doi:10.1016/j.Ifs.2005.09.011.

[19] Radwan MM, Ross SA, Slade D, Ahmed SA, Zulfiqar F, ElSohly MA. Isolation and characterization of new cannabis constituents from a high potency variety. Planta Med 2008;74(3):267-272. doi:10.1055 /s-2008-1034311.

[20] Radwan MM, ElSohly MA, Slade D, Ahmed SA, Wilson L, El-Alfy AT, et al. Non-cannabinoid constituents from a high potency cannabis sativa variety. Phytochemistry 2008;69(14):2627-2633. doi:10.1016/j. phytochem.2008.07.010.

[21] Ahmed SA, Ross SA, Slade D, Radwan MM, Zulfiqar F, ElSohly MA. Cannabinoid ester constituents from high-potency cannabis sativa. J Nat Prod 2008;71(4):536-542. doi:10.1021/np070454a.

[22] Choi YH, Hazekamp A, Peltenburg-Looman AM, Frédérich M, Erkelens C, Lefeber AW, et al. Nmr assignments of the major cannabinoids and cannabiflavonoids isolated from flowers of cannabis sativa. Phytochem Anal 2004;15(6):345-354. doi:10.1002/pca.787.

[23] Ross S, ElSohly M. Constituents of cannabis sativa L. Xxviii. A review of the natural constituents, 1980-1994. Zagazig J Pharm Sci 1995;4:1-10.

[24] Mechoulam R, Gaoni Y. Recent advances in the chemistry of hashish. In: Fortschritte der chemie organischer naturstoffe/progress in the chemistry of organic natural products/progrès dans la chimie des substances organiques naturelles. Vienna: Springer; 1967:175213. doi:10.1007/978-3-7091-8164-5 6.

[25] Gurley RJ, Aranow R, Katz M. Medicinal marijuana: A comprehensive review. J Psychoactive Drugs 1998;30(2):137-147. doi:10.1080/ 02791072.1998.10399683.

[26] Turner CE, Elsohly MA, Boeren EG. Constituents of cannabis sativa I. Xvii. A review of the natural constituents. J Nat Prod 1980;43(2):169_ 234. doi:10.1021/np50008a001.

[27] Gaoni Y, Mechoulam R. Structure+ synthesis of cannabigerol new hashish constituent. In: Proceedings of the Chemical Society, Royal soc chemistry thomas graham house, science park, milton rd, Cambridge cb4 0wf, cambs, England; 1964:82.

[28] Korte F, Sieper H. Zur chemischen klassifizierung von pflanzen: Xxiv.
Untersuchung von haschisch-inhaltsstoffen durch dünnschichtchromatographie. J Chromatogr A 1964;13:90-98. doi:10.1016/S00219673(01)95077-0.

[29] Crombie L, Ponsford R. Synthesis of hashish cannabinoids by terpenic cyclisation. Chem Commun (London) 1968;(15):894-895. doi:10.1039/C19680000894.

[30] Begley M, Clarke D, Crombie L, Whiting D. The x-ray structure of dibromocannabicyclol: Structure of bicyclomahanimbine. J Chem Soc D 1970;(22):1547-1548. doi:10.1039/C29700001547.

[31] Kane VV. Structure of cannabicyclol, a detailed nmr study of a synthetic analog. Tetrahedron Lett 1971;12(44):4101-4104. doi:10.1016/S0040-4039(01)97472-6.

[32] Choudhary N, Siddiqui M, Raoof K. Phytochemical aspect of cannabis sativa (I.). Res J Sci Tech 2013;5(2):284-288.

[33] Robson P. Therapeutic aspects of cannabis and cannabinoids. $\mathrm{Br} J$ Psychiatry 2001;178(2):107-115. doi:10.1192/bjp.178.2.107.

[34] Kumar RN, Chambers WA, Pertwee RG. Pharmacological actions and therapeutic uses of cannabis and cannabinoids. Anaesth 2001;56(11):1059-1068. doi:10.1111/j.1365-2044.2001.02269.x.

[35] Bowles DW, O'Bryant CL, Camidge DR, Jimeno A. The intersection between cannabis and cancer in the united states. Crit Rev Oncol Hematol 2012;83(1):1-10. doi:10.1016/j.critrevonc.2011.09.008.

[36] Gaoni Y, Mechoulam R. Isolation, structure, and partial synthesis of an active constituent of hashish. J Am Chem Soc 1964;86(8):16461647. doi:10.1021/ja01062a046.

[37] Robson P. Human studies of cannabinoids and medicinal cannabis. In: Cannabinoids. Springer; 2005:719-756. doi:10.1007/3-54026573-2 25 .

[38] Munson A, Harris L, Friedman M, Dewey W, Carchman R. Antineoplastic activity of cannabinoids. J Natl Cancer Inst 1975;55(3):597602. doi:10.1093/jnci/55.3.597.

[39] Galve-Roperh I, Sánchez C, Cortés ML, del Pulgar TG, Izquierdo M, Guzmán M. Anti-tumoral action of cannabinoids: Involvement of sustained ceramide accumulation and extracellular signal-regulated kinase activation. Nat Med 2000;6(3):313-319. doi:10.1038/73171.

[40] Sánchez C, de Ceballos ML, del Pulgar TG, Rueda D, Corbacho C, Velasco $\mathrm{G}$, et al. Inhibition of glioma growth in vivo by selective activation of the cb2 cannabinoid receptor. Cancer Res 2001;61(15):57845789.

[41] Casanova ML, Blázquez C, Martínez-Palacio J, Villanueva C, Fernández-Aceñero MJ, Huffman JW, et al. Inhibition of skin tumor growth and angiogenesis in vivo by activation of cannabinoid receptors. J Clin Invest 2003;111(1):43-50. doi:10.1172/JCI16116.

[42] Blázquez C, Carracedo A, Barrado L, Real PJ, Fernández-Luna JL, Velasco G, et al. Cannabinoid receptors as novel targets for the treatment of melanoma. FASEB J 2006;20(14):2633-2635. doi:10.1096/ fj.06-6638fje.

[43] Carracedo A, Gironella M, Lorente M, Garcia S, Guzmán M, Velasco $\mathrm{G}$, et al. Cannabinoids induce apoptosis of pancreatic tumor cells via endoplasmic reticulum stress-related genes. Cancer Res 2006;66(13):6748-6755. doi:10.1158/0008-5472.CAN-06-0169.

[44] Velasco G, Sánchez C, Guzmán M. Towards the use of cannabinoids as antitumour agents. Nat Rev Cancer 2012;12(6):436-444. doi:10.1038/nrc3247.

[45] Borrelli F, Pagano E, Romano B, Panzera S, Maiello F, Coppola D, et al. Colon carcinogenesis is inhibited by the trpm8 antagonist cannabigerol, a cannabis-derived non-psychotropic cannabinoid. Carcinogenesis 2014;35(12):2787-2797. doi:10.1093/carcin/bgu205.

[46] Mimeault M, Pommery N, Wattez N, Bailly C, Hénichart JP. Anti-proliferative and apoptotic effects of anandamide in human prostatic cancer cell lines: Implication of epidermal growth factor receptor down-regulation and ceramide production. Prostate 2003;56(1):112. doi:10.1002/pros.10190

[47] Melck D, De Petrocellis L, Orlando P, Bisogno T, Laezza C, Bifulco $M$, et al. Suppression of nerve growth factor trk receptors and prolactin receptors by endocannabinoids leads to inhibition of human breast and prostate cancer cell proliferation. Endocrinology 2000;141(1):118-126. doi:10.1210/endo.141.1.7239.

[48] Maccarrone M, Lorenzon T, Bari M, Melino G, Finazzi-Agrò A. Anandamide induces apoptosis in human cells via vanilloid receptors evidence for a protective role of cannabinoid receptors. J Biol Chem 
2000;275(41):31938-31945. doi:10.1074/jbc.M005722200.

[49] Sánchez C, Galve-Roperh I, Canova C, Brachet P, Guzmán M. $\Delta$ 9-tetrahydrocannabinol induces apoptosis in c6 glioma cells. FEBS Lett 1998;436(1):6-10. doi:10.1016/S0014-5793(98)01085-0.

[50] Aviello G, Romano B, Borrelli F, Capasso R, Gallo L, Piscitelli F, et al. Chemopreventive effect of the non-psychotropic phytocannabinoid cannabidiol on experimental colon cancer. J Mol Med (Berl) 2012;90(8):925-934. doi:10.1007/s00109-011-0856-x.

[51] Cianchi F, Papucci L, Schiavone N, Lulli M, Magnelli L, Vinci MC, et al. Cannabinoid receptor activation induces apoptosis through tumor necrosis factor $\alpha$-mediated ceramide de novo synthesis in colon cancer cells. Clin Cancer Res 2008;14(23):7691-7700. doi:10.1158/1078-0432.CCR-08-0799.

[52] Romano B, Borrelli F, Pagano E, Cascio MG, Pertwee RG, Izzo AA Inhibition of colon carcinogenesis by a standardized cannabis sativa extract with high content of cannabidiol. Phytomedicine 2014;21(5):631-639. doi:10.1016/j.phymed.2013.11.006.

[53] McKallip RJ, Lombard C, Fisher M, Martin BR, Ryu S, Grant S, et al. Targeting cb2 cannabinoid receptors as a novel therapy to treat malignant lymphoblastic disease. Blood 2002;100(2):627-634. doi:10.1182/blood-2002-01-0098.

[54] Ruiz L, Miguel A, Díaz-Laviada I. $\Delta$ 9-tetrahydrocannabinol induces apoptosis in human prostate pc-3 cells via a receptor-independent mechanism. FEBS letters 1999;458(3):400-404. doi:10.1016/S00145793(99)01073-X.

[55] De Petrocellis L, Melck D, Palmisano A, Bisogno T, Laezza C, Bifulco $M$, et al. The endogenous cannabinoid anandamide inhibits human breast cancer cell proliferation. Proc Natl Acad Sci U S A 1998;95(14):8375-8380.

[56] Melck D, Rueda D, Galve-Roperh I, De Petrocellis L, Guzmán M, Di Marzo V. Involvement of the camp/protein kinase a pathway and of mitogen-activated protein kinase in the anti-proliferative effects of anandamide in human breast cancer cells. FEBS lett 1999;463(3):235-240. doi:10.1016/S0014-5793(99)01639-7.

[57] Jacobsson SO, Rongård E, Stridh M, Tiger G, Fowler CJ. Serum-dependent effects of tamoxifen and cannabinoids upon c 6 glioma cell viability. Biochem Pharmacol 2000;60(12):1807-1813. doi:10.1016/ S0006-2952(00)00492-5.

[58] Mon MJ, Jansing RL, Doggett S, Stein JL, Stein GS. Influence of $\delta$ 9-tetrahydrocannabinol on cell proliferation and macromolecular biosynthesis in human cells. Biochem Pharmacol 1978;27(13):17591765. doi:10.1016/0006-2952(78)90553-1

[59] Blevins R, Smith D. Effects of delta-9-tetrahydrocannabinol on cultured hela cell growth and development. Growth 1980;44(2):133138.

[60] Guzmán M. Cannabinoids: Potential anticancer agents. Nat Rev Cancer 2003;3(10):745-755. doi:10.1038/nrc1188.

[61] Caffarel MM, Andradas C, Mira E, Pérez-Gómez E, Cerutti C, Moreno-Bueno G, et al. Cannabinoids reduce erbb2-driven breast cancer progression through akt inhibition. Mol Cancer 2010;9(196):45984599. doi:10.1186/1476-4598-9-196.

[62] Qamri Z, Preet A, Nasser MW, Bass CE, Leone G, Barsky SH, et al. Synthetic cannabinoid receptor agonists inhibit tumor growth and metastasis of breast cancer. Mol Cancer Ther 2009;8(11):31173129. doi:10.1158/1535-7163.MCT-09-0448.

[63] Pisanti S, Malfitano AM, Grimaldi C, Santoro A, Gazzerro P, Laezza $C$, et al. Use of cannabinoid receptor agonists in cancer therapy as palliative and curative agents. Best Pract Res Clin Endocrinol Metab 2009;23(1):117-131. doi:10.1016/j.beem.2009.02.001.

[64] Flygare J, Sander B. The endocannabinoid system in cancer-potential therapeutic target?. Semin Cancer Biol 2008;18(3):176-189. doi:10.1016/j.semcancer.2007.12.008.

[65] Bifulco M, Laezza C, Portella G, Vitale M, Orlando P, De Petrocellis $\mathrm{L}$, et al. Control by the endogenous cannabinoid system of ras oncogene-dependent tumor growth. FASEB J 2001;15(14):2745-2747. doi:10.1096/fj.01-0320fje.

[66] Ligresti A, Bisogno T, Matias I, De Petrocellis L, Cascio MG, Cosenza V, et al.Possible endocannabinoid control of colorectal cancer growth. Gastroenterology 2003;125(3):677-687. doi:10.1016/S0016-5085(03) 00881-3.

[67] McKallip RJ, Nagarkatti M, Nagarkatti PS. $\Delta$-9-tetrahydrocannabinol enhances breast cancer growth and metastasis by suppression of the antitumor immune response. J Immunol 2005;174(6):32813289. doi:10.4049/jimmunol.174.6.3281.

[68] Jacobsson SO, Wallin T, Fowler CJ. Inhibition of rat c6 glioma cell proliferation by endogenous and synthetic cannabinoids. Relative involvement of cannabinoid and vanilloid receptors. J Pharmacol Exp Ther 2001;299(3):951-959.

[69] Contassot E, Tenan M, Schnüriger V, Pelte M-F, Dietrich P-Y. Arachidonyl ethanolamide induces apoptosis of uterine cervix cancer cells via aberrantly expressed vanilloid receptor-1. Gynecol Oncol 2004;93(1):182-188. doi:10.1016/j.ygyno.2003.12.040.

[70] Xu X, Liu Y, Huang S, Liu G, Xie C, Zhou J, et al. Overexpression of cannabinoid receptors $\mathrm{cb} 1$ and $\mathrm{cb} 2$ correlates with improved prognosis of patients with hepatocellular carcinoma. Cancer Genet Cytogenet 2006;171(1):31-38. doi:10.1016/j.cancergencyto.2006.06.014.

[71] Di Marzo V. Targeting the endocannabinoid system in cancer therapy: A call for further research. Nat Med 2002;8(6):547-550. doi:10.1038/nm0602-547

[72] Salazar M, Carracedo A, Salanueva Í, Hernández-Tiedra S, Lorente $M$, Egia $A$, et al. Cannabinoid action induces autophagy-mediated cell death through stimulation of ER stress in human glioma cells. J Clin Invest 2009;119(5):1359-1372. doi:10.1172/JCI37948.

[73] Kogan NM. Cannabinoids and cancer. Mini-Rev Med Chem 2005;5(10):941-952.

[74] Guzmán M, Sánchez C, Galve-Roperh I. Cannabinoids and cell fate. Pharmacol Ther 2002;95(2):175-184. doi:10.1016/S01637258(02)00256-5.

[75] Massi P, Vaccani A, Ceruti S, Colombo A, Abbracchio MP, Parolaro D. Antitumor effects of cannabidiol, a nonpsychoactive cannabinoid, on human glioma cell lines. J Pharmacol Exp Ther 2004;308(3):838845. doi:10.1124/jpet.103.061002.

[76] Torres S, Lorente M, Rodríguez-Fornés F, Hernández-Tiedra S, Salazar M, García-Taboada E, et al. A combined preclinical therapy of cannabinoids and temozolomide against glioma. Mol Cancer Ther 2011;10(1):90-103. doi:10.1158/1535-7163.MCT-10-0688.

[77] Guzman M, Duarte M, Blazquez C, Ravina J, Rosa M, Galve-Roperh I, et al. A pilot clinical study of 89 -tetrahydrocannabinol in patients with recurrent glioblastoma multiforme. $\mathrm{Br} J$ Cancer 2006;95(2):197-203. doi:10.1038/sj.bjc.6603236.

[78] Ellert-Miklaszewska A, Grajkowska W, Gabrusiewicz K, Kaminska $B$, Konarska L. Distinctive pattern of cannabinoid receptor type ii (cb2) expression in adult and pediatric brain tumors. Brain Res 2007;1137(1):161-169. doi:10.1016/j.brainres.2006.12.060.

[79] Baselga J, Swain SM. Novel anticancer targets: Revisiting erbb2 and discovering erbb3. Nat Rev Cancer 2009;9(7):463-475. doi:10.1038/ nrc2656.

[80] Ligresti A, Moriello AS, Starowicz K, Matias I, Pisanti S, De Petrocellis $L$, et al. Antitumor activity of plant cannabinoids with emphasis on the effect of cannabidiol on human breast carcinoma. J Pharmacol Exp Ther 2006;318(3):1375-1387. doi:10.1124/jpet.106.105247.

[81] McAllister SD, Christian RT, Horowitz MP, Garcia A, Desprez PY. Cannabidiol as a novel inhibitor of id-1 gene expression in aggressive breast cancer cells. Mol Cancer Ther 2007;6(11):2921-2927. doi:10.1158/1535-7163.MCT-07-0371.

[82] Benezra R, Davis RL, Lockshon D, Turner DL, Weintraub H. The protein id: A negative regulator of helix-loop-helix DNA binding proteins. Cell 1990;61(1):49-59. doi:10.1016/0092-8674(90)90214-Y.

[83] Perk J, lavarone A, Benezra R. Id family of helix-loop-helix proteins in cancer. Nat Rev Cancer 2005;5(8):603-614. doi:10.1038/nrc1673.

[84] Fong S, Itahana Y, Sumida T, Singh J, Coppe J-P, Liu Y, et al. Id-1 as a molecular target in therapy for breast cancer cell invasion and metastasis. Proc Natl Acad Sci U S A 2003;100(23):13543-13548. doi:10.1073/pnas.2230238100.

[85] Murase R, Kawamura R, Singer E, Pakdel A, Sarma P, Judkins J, et al. Targeting multiple cannabinoid anti-tumour pathways with a resorcinol derivative leads to inhibition of advanced stages of breast cancer. Br J Pharmacol 2014;171(19):4464-4477. doi:10.1111/ bph.12803.

[86] Caffarel MM, Sarrió D, Palacios J, Guzmán M, Sánchez C. $\Delta$ 9tetrahydrocannabinol inhibits cell cycle progression in human breast cancer cells through cdc2 regulation. Cancer Res 2006;66(13):6615- 
6621. doi:10.1158/0008-5472.CAN-05-4566.

[87] Siegel R, Naishadham D, Jemal A. Cancer statistics, 2013. Ca-Cancer J Clin 2013;63(1):11-30.

[88] Kriza C, Emmert M, Wahlster P, Niederländer C, Kolominsky-Rabas P. Cost of illness in colorectal cancer: An international review. Pharmacoeconomics 2013;31(7):577-588. doi:10.1007/s40273-013-00554.

[89] Vara D, Salazar M, Olea-Herrero N, Guzmán M, Velasco G, Díaz-Laviada I. Anti-tumoral action of cannabinoids on hepatocellular carcinoma: Role of ampk-dependent activation of autophagy. Cell Death Differ 2011;18(7):1099-1111. doi:10.1038/cdd.2011.32.

[90] Preet A, Ganju R, Groopman J. $\Delta 9$-tetrahydrocannabinol inhibits epithelial growth factor-induced lung cancer cell migration in vitro as well as its growth and metastasis in vivo. Oncogene 2008;27(3):339346. doi:10.1038/sj.onc.1210641.

[91] Sarfaraz S, Adhami VM, Syed DN, Afaq F, Mukhtar H. Cannabinoids for cancer treatment: Progress and promise. Cancer Res 2008;68(2):339-342. doi:10.1158/0008-5472.CAN-07-2785.

[92] Flygare J, Gustafsson K, Kimby E, Christensson B, Sander B. Cannabinoid receptor ligands mediate growth inhibition and cell death in mantle cell lymphoma. FEBS Lett 2005;579(30):6885-6889. doi:10.1016/j.febslet.2005.11.020.

[93] Gustafsson K, Christensson B, Sander B, Flygare J. Cannabinoid receptor-mediated apoptosis induced by $r(+)$-methanandamide and win55, 212-2 is associated with ceramide accumulation and p38 activation in mantle cell lymphoma. Mol Pharmacol 2006;70(5):16121620. doi:10.1124/mol.106.025981.

[94] Sarfaraz S, Afaq F, Adhami VM, Mukhtar H. Cannabinoid receptor as a novel target for the treatment of prostate cancer. Cancer Res 2005;65(5):1635-1641. doi:10.1158/0008-5472.CAN-04-3410.

[95] Kogan NM, Schlesinger M, Peters M, Marincheva G, Beeri $R$, Mechoulam R. A cannabinoid anticancer quinone, hu-331, is more potent and less cardiotoxic than doxorubicin: A comparative in vivo study. J Pharmacol Exp Ther 2007;322(2):646-653. doi:10.1124/ jpet.107.120865.

[96] Watson SJ, Benson JA, Joy JE. Marijuana and medicine: Assessing the science base: A summary of the 1999 institute of medicine report. Arch Gen Psychiatry 2000;57(6):547-552.

[97] Carey MP, Burish TG, Brenner DE. Delta-9-tetrahydrocannabinol in cancer chemotherapy: Research problems and issues. Ann Intern Med 1983;99(1):106-114. doi:10.7326/0003-4819-99-1-106.

[98] Levitt M. Cannabinoids as antiemetics in cancer chemotherapy. 1986.

[99] Ungerleider JT, Andrysiak T, Fairbanks L, Goodnight J, Sarna G, Jamison K. Cannabis and cancer chemotherapy. Cancer 1982;50:636645.

[100] Tramèr MR, Carroll D, Campbell FA, Reynolds DJM, Moore RA, McQuay HJ. Cannabinoids for control of chemotherapy induced nausea and vomiting: Quantitative systematic review. BMJ 2001;323(7303):16-21. doi:10.1136/bmj.323.7303.16.

[101] Noyes R Jr, Brunk SF, Avery D, Canter A. The analgesic properties of delta-9-tetrahydrocannabinol and codeine. Clin Pharmacol Ther
1975;18(1):84-89. doi:10.1002/cpt197518184.

[102] Noyes R, Brunk S, Baram DA, Canter A. Analgesic effect of delta 9-tetrahydrocannabinol. J Clin Pharmacol 1975;15(2-3):139-143. doi:10.1002/j.1552-4604.1975.tb02348.x.

[103] Staquet M, Gantt C, Machin D. Effect of a nitrogen analog of tetrahydrocannabinol on cancer pain. Clin Pharmacol Ther 1978;23(4):397401. doi:10.1002/cpt1978234397.

[104] Russo EB. Cannabis and cannabinoids: Pharmacology, toxicology, and therapeutic potential, 1st ed. New York: The Haworth Press; 2002.

[105] Walsh D, Nelson KA, Mahmoud F. Established and potential therapeutic applications of cannabinoids in oncology. Support Care Cancer 2003;11(3):137-143. doi:10.1007/s00520-002-0387-7.

[106] Mechoulam R, Parker LA, Gallily R. Cannabidiol: An overview of some pharmacological aspects. J Clin Pharmacol 2002;42(11 Suppl):11S-19S. doi:10.1002/j.1552-4604.2002.tb05998.x.

[107] Pertwee RG. The pharmacology and therapeutic potential of cannabidiol. Cannabinoids. Kluwer Academic/Plenum Publishers. 2004:32-83.

[108] Bornheim LM, Grillo MP. Characterization of cytochrome p450 3a inactivation by cannabidiol: Possible involvement of cannabidiol-hydroxyquinone as a p450 inactivator. Chem Res Toxicol 1998;11(10):1209-1216. doi:10.1021/tx9800598.

[109] Russo E, Guy GW. A tale of two cannabinoids: The therapeutic rationale for combining tetrahydrocannabinol and cannabidiol. Med Hypotheses 2006;66(2):234-246. doi:10.1016/j.mehy.2005.08.026.

[110] Ilan A, Gevins A, Coleman M, ElSohly M, De Wit H. Neurophysiological and subjective profile of marijuana with varying concentrations of cannabinoids. Behav Pharmacol 2005;16(5-6):487-496.

[111] Min KW, Lee SH, Baek SJ. Moonlighting proteins in cancer. Cancer Lett 2016;370(1):108-116. doi:10.1016/j.canlet.2015.09.022.

[112] Jeffery CJ. Moonlighting proteins. Trends Biochem Sci 1999;24(1):811. doi:10.1016/S0968-0004(98)01335-8.

[113] Mathew M, Chang C, Vaishak A, Haipeng L, Tanu M, Grant Z, et al. MoonProt: a database for proteins that are known to moonlight. Nucleic Acids Res 2015;43(Database issue):D277-D282. doi:10.1093/ nar/gku954.

[114] ATF2 activating transcription factor 2 [Homo sapiens (human)] Gene ID: 1386, [Updated on 11- Jun-2017]. Available from: https://www. ncbi.nlm.nih.gov/gene/1386.

[115] MAPK1 mitogen-activated protein kinase 1 [Homo sapiens (human)] Gene ID: 5594, [Updated on 11-Jun-2017]. Available from: https:// www.ncbi.nlm.nih.gov/gene/5594.

[116] Carracedo A, Lorente M, Egia A, Blázquez C, García S, Giroux V, et al. The stress-regulated protein $\mathrm{p} 8$ mediates cannabinoid-induced apoptosis of tumor cells. Cancer cell 2006;9(4):301-312. doi:10.1016/j. ccr.2006.03.005.

[117] Sarfaraz S, Afaq F, Adhami VM, Malik A, Mukhtar H. Cannabinoid receptor agonist-induced apoptosis of human prostate cancer cells Incap proceeds through sustained activation of erk1/2 leading to g1 cell cycle arrest. J Biol Chem 2006;281(51):39480-39491. doi:10.1074/jbc.M603495200. 